\title{
Accuracy Training Program: Can Improve Shooting Results of Petanque Athletes Aged 15-20 Years?
}

\author{
Diajeng Tyas Pinru Phytanza ${ }^{1,2}$, Erick Burhaein ${ }^{3,4, *}$, Subur Indriawan ${ }^{5}$, \\ Carla Cristina Vieira Lourenço ${ }^{6}$, Nevzat Demirci ${ }^{7}$, Puput Widodo ${ }^{3}$, Ibnu Prasetyo Widiyono ${ }^{3}$, \\ Yogi Ferdy Irawan ${ }^{3}$, Wisnu Guntur Sutopo ${ }^{3}$, Mokhamad Parmadi ${ }^{3}$, Alfiah Rizqi Azizah ${ }^{3}$, \\ Muhammad Saleh $^{8}$, Agus Hadiatmo ${ }^{3}$, Ari Susanto ${ }^{9}$ \\ ${ }^{1}$ Department of Special Education, Faculty of Education, Universitas Negeri Yogyakarta, \\ Yogyakarta, 55281, Daerah Istimewa Yogyakarta, Indonesia \\ ${ }^{2}$ Doctoral Program of Education Science, Faculty of Education, Universitas Negeri Yogyakarta, \\ Yogyakarta, 55281, Daerah Istimewa Yogyakarta, Indonesia \\ ${ }^{3}$ Department of Sports Education, Faculty of Teacher Training and Education, Universitas Ma'arif Nahdlatul Ulama Kebumen, \\ Kebumen, 54316, Jawa Tengah, Indonesia \\ ${ }^{4}$ Doctoral Program of Sports Education, School Postgraduates Studies, Universitas Pendidikan Indonesia, \\ Bandung, 40154, Jawa Barat, Indonesia \\ ${ }^{5}$ Bachelor Program of Sports Education, Faculty of Teacher Training and Education, Universitas Ma'arif Nahdlatul Ulama Kebumen, \\ Kebumen, 54316, Jawa Tengah, Indonesia \\ ${ }^{6}$ Department of Sport of Science, Faculty of Human and Social Sciences, University of Beira Interior, Covilhã, 6201-001, Portugal \\ ${ }^{7}$ Department of Coaching Education, Faculty of Sports Sciences, Mersin University, Mersin, 33343, Turkey \\ ${ }^{8}$ Physical Education Health and Recreation, Faculty of Teacher Training and Education, Universitas Muhammadiyah Sukabumi, \\ Sukabumi, 43113, Jawa Barat, Indonesia \\ ${ }^{9}$ Library, Universitas Ma’arif Nahdlatul Ulama Kebumen, Kebumen, 54316, Jawa Tengah, Indonesia
}

Received December 19, 2021; Revised February 12, 2022; Accepted February 23, 2022

\section{Cite This Paper in the following Citation Styles}

(a): [1] Diajeng Tyas Pinru Phytanza, Erick Burhaein, Subur Indriawan, Carla Cristina Vieira Lourenço, Nevzat Demirci, Puput Widodo, Ibnu Prasetyo Widiyono, Yogi Ferdy Irawan, Wisnu Guntur Sutopo, Mokhamad Parmadi, Alfiah Rizqi Azizah, Muhammad Saleh, Agus Hadiatmo, Ari Susanto , "Accuracy Training Program: Can Improve Shooting Results of Petanque Athletes Aged 15-20 Years?," International Journal of Human Movement and Sports Sciences, Vol. 10, No. 1, pp. 121 - 130, 2022. DOI: 10.13189/saj.2022.100117.

(b): Diajeng Tyas Pinru Phytanza, Erick Burhaein, Subur Indriawan, Carla Cristina Vieira Lourenço, Nevzat Demirci, Puput Widodo, Ibnu Prasetyo Widiyono, Yogi Ferdy Irawan, Wisnu Guntur Sutopo, Mokhamad Parmadi, Alfiah Rizqi Azizah, Muhammad Saleh, Agus Hadiatmo, Ari Susanto (2022). Accuracy Training Program: Can Improve Shooting Results of Petanque Athletes Aged 15-20 Years?. International Journal of Human Movement and Sports Sciences, 10(1), 121 - 130. DOI: 10.13189/saj.2022.100117.

Copyright $\odot 2022$ by authors, all rights reserved. Authors agree that this article remains permanently open access under the terms of the Creative Commons Attribution License 4.0 International License

\begin{abstract}
The background in this study is the shooting ability of petanque athletes whose achievements are inconsistent during the match/competition. This study aims to find out the effect of accuracy training on the results of shooting games of petanque athletes. Participants in the study were 20 athletes (ages 15-20 years; $\mathrm{M}=17.7$; SD: 2.4). This research design is one group pretest-posttest experimental design. The instruments used for the test of ability (shooting) are game numbers (shooting station) 1-5 with a distance of 6-9 meters. Data analysis uses a t-test with the help of IBM SPSS 24. Based on the calculation of
\end{abstract}

pretest and posttest data on the shooting results of petanque athletes who have obtained an accuracy training program, it shows a value of $p=0.000$ which means that $p<0.05$ so that $\mathrm{H} 0$ is rejected and $\mathrm{H} 1$ is accepted. Therefore it can be concluded that there is an influence between the accuracy training program on shooting results in petanque athletes aged 15-20 years. This study contributed to subsequent research to involve other factors that can improve the shooting ability of petanque athletes.

Keywords Accuracy Training, Ages 15-20, Athletes, 
Petanque, Shooting

\section{Introduction}

Petanque is a new sport in the world that uses small balls made of iron in other words the "bosi" (iron ball). Petanque's game is making 13 points and preventing opponents from reaching that number [1]-[3]. Confederation Mondiale Sport Boules, Petanque is a game (boule) by throwing an iron ball closer to a wooden ball (Jack) and both feet must form a small circle (hoop), there is also a special competition for shooting matches [4]-[6].

Petanque sports characters tend to require accuracy and concentration when playing this sport, petanque sports can be played by anyone, from children to adults even parents can be even fat people and skinny people. To throw an iron ball requires calmness, balance, and accuracy of the athlete's body [7]-[9]. If the athlete's body is shaky or the standing is unstable then the iron ball rate is not straight with the existing target and causes the iron ball to be far from the target. There are several numbers contested in petanque sports such as triple men's women, double men's women, men's singles women, and shooting men's women. There are 2 types of throws in petanque sports, namely pointing and shooting [10]-[12].

Pointing is a type of throw to bring the iron ball closer to the "boka" (wooden ball) or as a target in a petanque game, aiming to get closer than the opponent's iron ball which is the beginning of the game strategy that will be carried out in a petanque match [13]-[15]. Pointing in a petanque match is a strategy to survive. Usually, beginner athletes often do this strategy as well as when the iron ball left one. Shooting is a type of throw to throw the opponent's iron ball close to the wooden ball, so the opponent's iron ball becomes away from the wooden ball. One of the most important aspects of the petanque game is shooting. Petanque is a team sport. When the shooting performance of some athletes is weak, it will affect the team's performance to be weak and difficult to compete in petanque matches, so there will be defeat [16]-[18].

The shooting match number is done at a distance of six meters, seven meters, eight meters, and nine meters with the acquisition of $0,1,3$, and 5 points for each shot achieved at a certain level. Shooters are only given one shot each distance given at each level. Petanque games are included in sports that have the goal of achieving maximum accuracy [19]-[21]. This means that the throw must be right on a certain target to get the winning points. Based on the statement above accuracy affects the shooting number, the more precise the throw on the obstacle given, the more points obtained. Making the right throw on target requires the right methods. The coach must be creative in providing an exercise program to his athletes, in addition to the components that affect the success of shooting must also be considered, namely: Ball grip (a technique in holding the iron ball), Position of the body leads to the target (straightness of body with target), the static balance of limbs, Low body position and leaning forward, Release the ball and follow through Saddle [1], [22]-[24]. It still can't be applied on the petanque team.

Based on the results of observations made by researchers in the training area of petanque team athletes who are located in the training area of the petanque team athletes have not been fully focused, just regular training, the training time is also too little, less than 2 hours for the technical training in one week. This is due to a lack of supervision from the coach in full and less strict rules on the athletes. Petanque teams are also only formed in 2017 and existing athletes until now have not added or regenerated and who have become athletes still often train for less weighted reasons. Lack of supervision of a coach, making athletes only train mediocre, namely only guided by training as they know through direct observation at some events and electronic media such as youtube. Most petanque team athletes are still not consistent in shooting, because there are still many balances that are less balanced and their arms are less raised or straightforward. At a glance, there are still a lot petanque team athletes who do not know about the specs that are in it such as what techniques and training models are appropriate to improve their ability to compete fiercely with athletes in other regions.

The rapid development of petanque sports in the world and the increasing number of targets of training variations both pointing and shooting applied by some coaches, shooting training models using barrier media placed before the target ball and training by inserting the iron ball into the car tire circle or motorcycle tire is the right method to improve the shooting ability of petanque team athletes [25]-[28]. With the existence of barrier media, the hope is to increase consistency when shooting so that the iron ball rate slightly lifts or upwards.

Based on the urgency of this research, the following research question is raised "Can accuracy training program improve shooting results of petanque athletes aged 15-20 years?".

\section{Materials and Methods}

\subsection{Research Method}

Quantitative research is used to find numerical data and analyze the findings [29]. This research will use experimental methods. The research design used is one group's pretest-posttest design, which is a research design that examines one group of pretests before being given treatment and posttest after being given treatment [30], [31]. Thus it can be known more accurately because it can compare withheld before being given treatment.

With the exercise provided, there will be a causal 
relationship as an influence of the implementation of the exercise. In this study, the authors wanted to know the difference in results better between shooting exercises with accuracy and shooting exercises without accuracy to the shooting results of petanque team athletes. Then from these results, coaches or athletes can use and even develop an exercise model as used by the author provided to the research subject for variations in his exercise program. The design in this study is described in Figure 1.

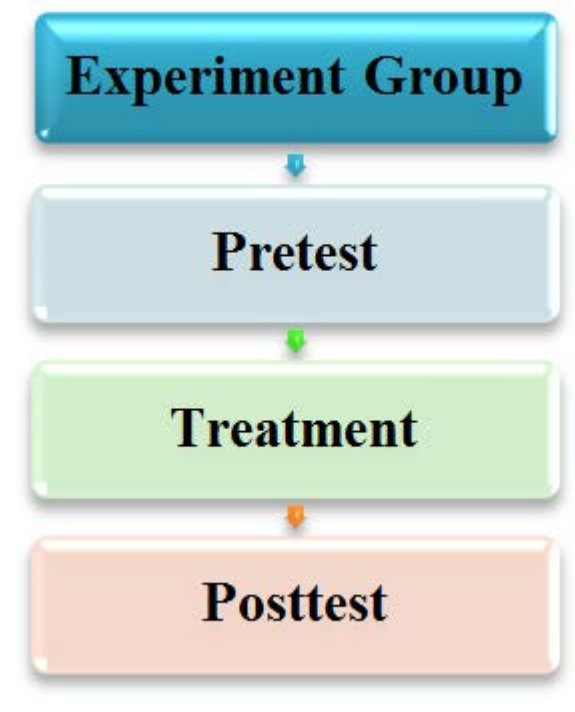

Figure 1. Flow Chart or Research Design

\subsection{Participant}

Study participants were selected from the study population [30]. The population in the study was petanque athletes. This research uses purposive sampling, this technique is based on a specific goal or criterion [30], [32]. The criteria that must be met in determining the participants of this study, namely:

(1) Petanque team athletes.
(2) Aged 15-20 years ( $M=17.7$; SD: 2.4$)$

(3) At least have been training at the team/club for two years.

(4) Willing to follow the exercise program during the study.

This sampling technique sorted the population of athletes into 20 petanque athletes who were participants in the study. The 20 athletes consist of 12 men and 8 petanque athletes.

\subsection{Instruments}

The instrument in the study is the petanque sports test shooting. The instructions for instruments in this study are as follows:

(1) Objective: This test aims to measure the accuracy of athletes when shooting.

(2) Tools and facilities include (1) Bosi, circle, station shooting game, and stationery. The distance between standing positions and targets is 6-9 meters.

(3) Test officer: Observer and record-taker of results.

(4) Implementation: (1) Initial stance: First stand on the circle and hold the ball then look straight towards the target (2) Movement: Participants take the prefix with the body leaning forward and the arms swung backward. Then the participant swings in front of the arm and releases the ball in the hand towards the target. (3) Participants must complete the shooting circuit until station 5 .

(5) Record result: the recorded result is a point of $1 \mathrm{x}$ throw of the ball.

More details are presented below. The shooting game station can be seen in Figure 2. The calculation of the shooting game station is in Figure 3. The field station shooting game can be seen in Figure 4 


\section{SHOOTING COMPETITION}

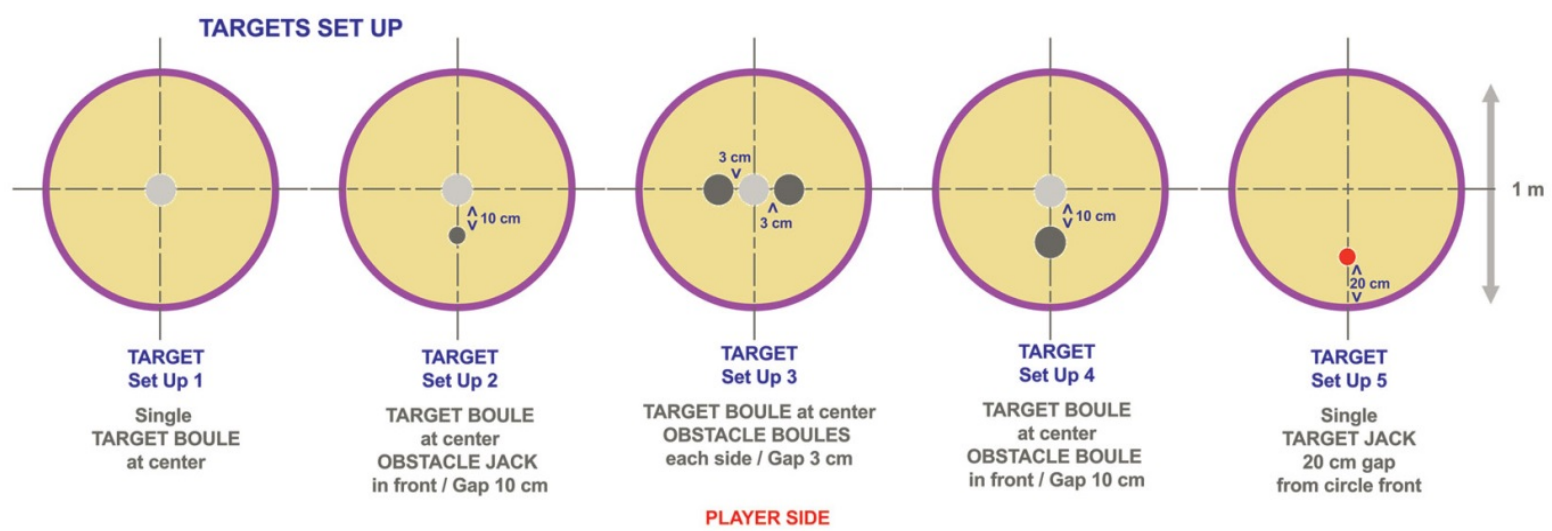

OBJECTS

FIELD LAYOUT

VALID SHOT Landing Boule Area

TARGET BOULE diameter: $74 \mathrm{~mm}$ smooth \& light color

OBSTACLE BOULE diameter: $74 \mathrm{~mm}$ weight: $700 \mathrm{gr}$ smooth \& dark color

- tARGET JACK Light color

- OBSTACLE JACK Dark color

\section{Shooting circles} Diameter $50 \mathrm{~cm}$

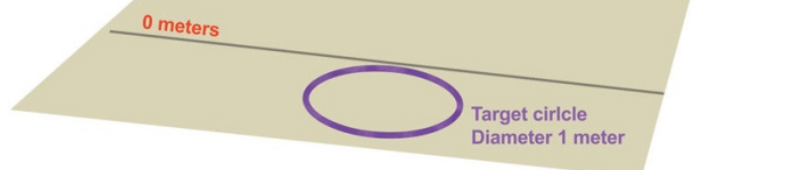

POINT RULES:

TOTAL NUMBER OF SHOTS / ROUND : 20 shots 4 shots at each target set up;

one at each shooting position: $6 \mathrm{~m} / 7 \mathrm{~m} / 8 \mathrm{~m} / 9 \mathrm{~m}$ MAXIMUM Score $=100 \mathrm{pts}$

Get 5 pts when:

Valid shot on target,

the obstacle(s) didn't move ;

the target end up out of the circle

and the shooting boule stay in the circle.

\section{Get 3 pts when:}

Valid shot on target,

the obstacle(s) didn't move

the target end up out of the circle.

In set up 5, the jack is hit but still inside circle area

\section{Get 1 pt when:}

Valid shot on target hit correctly but

target stay in circle and/or obstacle moves after correct shot on target

Source: PB FOPI [33]

Figure 2. Shooting game station

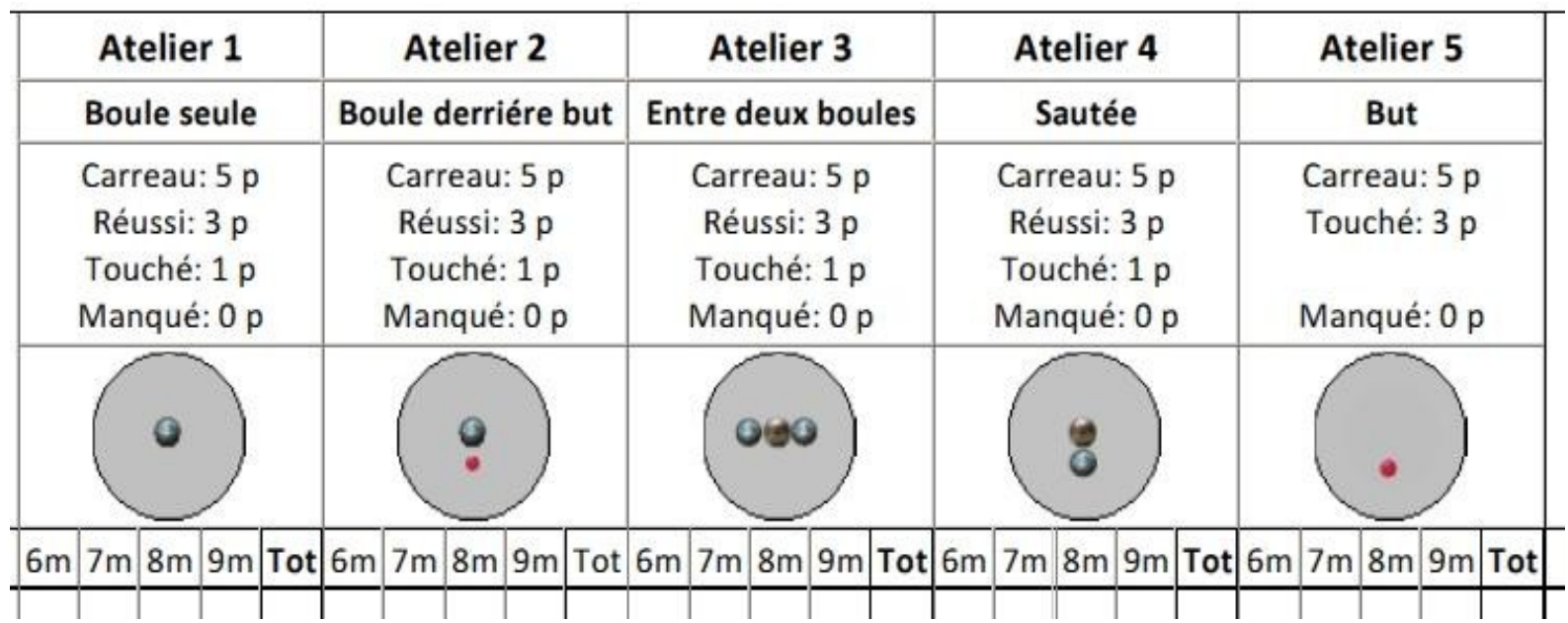

Source: PB FOPI [30]

Figure 3. Calculation of Shooting Game Station

Information:

Atelier $=$ Discipline/Station/level
Carreau $=$ The shooting ball is in the target circle, the target ball is out and this will get 5 points. 
Reussi= The shooting ball and the target ball come out if it happens like this get 3 points.

Touche $=$ The shooting ball only touches the target ball, the target ball does not come out of the circle, if it happens like this get 1 point.

Manque $=$ Not hitting the target or the ball thrown fall outside the target ball circle it will get point 0 .

\subsection{Data Collection Technique}

The data collection in this study is by measuring tests that are shooting tests. This test is used for initial measurement (pretest) and final measurement (posttest) i.e. using test shooting games. In the pretest and postest range, an exercise program was conducted for 16 meetings. The details are three times in one week, Tuesday, Thursday, and Saturday. The exercise program is detailed in the appendix (Table $1 \& 2$ ).

\subsection{Data Analysis}

Statistical tests on this study are included in parametric statistics. Parametric statistics is a statistical test that requires a prerequisite test, while the prerequisite test used in this study, namely the test of normality and homogeneity [34].

The normality test is nothing but a test against the normal distribution of data to be analyzed. Testing is done depending on the variables to be processed. To test the normality of research data using the Kolmogorov-Smirnov rule with the help of SPSS. Kolmogorov Smirnov's method, the testing criteria are as follows: 1 ) The significance value is less than 0.05 , then the data is not normally distributed; 2) While the significance value is more than 0.05 , then the data is normally distributed [34].

The next step is the homogeneity test which will show that the data comes from a homogeneous area. The homogeneity test used the $\mathrm{F}$ test of pretest data in both groups using the help of the IBM SPSS 24 program.

After the prerequisite test then the next is the hypothesis test. Hypothesis testing uses the t-test by comparing the mean between group 1 and group 2 . When the signification value, is more than 0.05 , then the result is insignificant, the result of the acquisition of a significance that is less than 0.05 , means that the data is different/significantly influential [34].

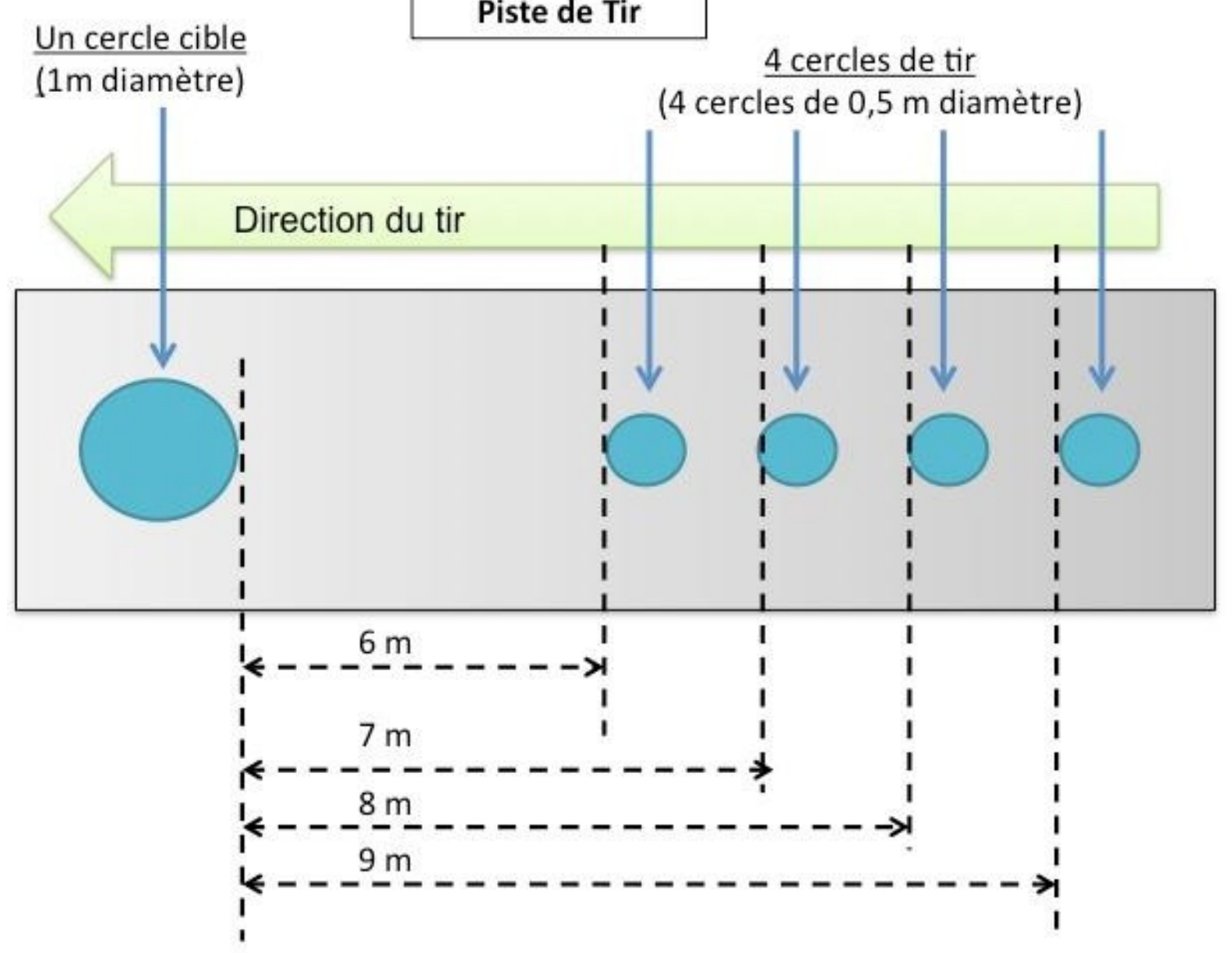

Figure 4. Field station shooting game 


\section{Results}

\subsection{Descriptive Statistical Data}

Descriptive data in this study is presented in two forms. The first is the pretest, posttest, and the difference in the increase from petanque shooting test results. The pretest, postest, and difference in increases can be observed in Table 1.

Table 1. Pretest, Postest, and Difference in Increases

\begin{tabular}{|c|c|c|c|}
\hline Subject & Pretest & Posttest & Increased \\
\hline 1 & 18 & 22 & 4 \\
\hline 2 & 25 & 36 & 11 \\
\hline 3 & 24 & 34 & 10 \\
\hline 4 & 14 & 19 & 5 \\
\hline 5 & 10 & 17 & 7 \\
\hline 6 & 12 & 15 & 3 \\
\hline 7 & 10 & 20 & 10 \\
\hline 8 & 9 & 13 & 4 \\
\hline 9 & 0 & 5 & 5 \\
\hline 10 & 11 & 12 & 1 \\
\hline 11 & 9 & 15 & 6 \\
\hline 12 & 8 & 13 & 5 \\
\hline 13 & 10 & 17 & 7 \\
\hline 14 & 0 & 5 & 5 \\
\hline 15 & 7 & 10 & 3 \\
\hline 16 & 8 & 10 & 2 \\
\hline 17 & 15 & 20 & 5 \\
\hline 18 & 7 & 13 & 6 \\
\hline 19 & 3 & 10 & 7 \\
\hline \multirow[t]{2}{*}{20} & 0 & 5 & 5 \\
\hline & 200 & 311 & 111 \\
\hline
\end{tabular}

The second is descriptive statistical data in the form of mean, median, mode, standard deviation, variant, range, minimum, and maximum.

This data is presented in detail, namely pretest data and posttest petanque shooting test results in table 2 .

Table 2. Descriptive Statistics Data (Pretest \& Posttest)

\begin{tabular}{|c|c|c|c|}
\hline \multicolumn{4}{|c|}{ Descriptive Statistics } \\
\hline & & Pretest & Posttest \\
\hline \multirow{2}{*}{$\mathrm{N}$} & Valid & 20 & 20 \\
\hline & Missing & 0 & 0 \\
\hline \multicolumn{2}{|c|}{ Mean } & 10.00 & 15.55 \\
\hline \multicolumn{2}{|c|}{ Median } & 9.50 & 14.00 \\
\hline \multicolumn{2}{|c|}{ Mode } & 0 & 5 \\
\hline \multicolumn{2}{|c|}{ Std. Deviation } & 6.91 & 8.32 \\
\hline \multicolumn{2}{|c|}{ Variance } & 47.79 & 69.21 \\
\hline \multicolumn{2}{|c|}{ Range } & 25 & 31 \\
\hline \multicolumn{2}{|c|}{ Minimum } & 0 & 5 \\
\hline \multicolumn{2}{|c|}{ Maximum } & 25 & 36 \\
\hline
\end{tabular}

The table 2 shows the shooting results of 20 petanque athletes who became the experimental group, with an average of 10.00 and a raw deviation of 6.91 . While the highest score is 25 and the lowest score is 0 . The ability of petanque team athletes to shoot results at the time of posttest data collection is with an average of 15.55 and a raw deviation of 8.32. While the highest score is 36 and the lowest score is 5 . These results have seen an increase in the shooting ability of athletes.

\subsection{Test Data Analysis Requirements}

Before carrying out statistical analysis, assumptions were first tested (test-normality \& test-homogeneity). The normality test is to determine the level of normality of the data distribution, while the homogeneity test is to determine the data source coming from a homogeneous area.

Normality testing uses the kolmogorov smirnov test. This test will test the hypothesis of samples originating from normally distributed populations, to accept or reject the hypothesis by comparing the price of Asymp. Sig. with 0.05. The criteria accept the hypothesis when Asymp. Sig. Greater than 0.05, if it does not meet the criteria then the hypothesis is not normal/rejected. The output of the data normality test can be observed in Table 3

Table 3. The Output of Normality Test

\begin{tabular}{|c|c|c|c|}
\hline \multicolumn{4}{|c|}{ Normality test calculation } \\
\hline No & Variable & $\begin{array}{c}\text { Asymp. } \\
\text { Sig. }\end{array}$ & Conclusion \\
\hline $\mathbf{1}$ & $\begin{array}{c}\text { Pretest Shooting } \\
\text { Results }\end{array}$ & 0.200 & Normal \\
\hline $\mathbf{2}$ & $\begin{array}{c}\text { Posttest Shooting } \\
\text { Results }\end{array}$ & 0.200 & Normal \\
\hline
\end{tabular}

From the table above the Asymp price. Sig. Of the variables, all greater than 0.05 , the hypothesis is that a sample based on a normally distributed population is accepted.

Once the data is normal, the next step is homogeneity testing. The output of the homogeneity test can be observed in Table 4.

Table 4. Results of Homogeneity Test Calculation

\begin{tabular}{|c|c|c|}
\hline \multicolumn{3}{|c|}{ Test of Homogeneity of Variances } \\
\hline Variable & Sig. & Conclusion \\
\hline $\begin{array}{c}\text { The Effect of Accuracy } \\
\text { Exercises }\end{array}$ & 0.530 & Homogenous \\
\hline
\end{tabular}

From the calculation obtained Sig. $>0.05$, means that the sample variant is said to be homogeneous, so the hypothesis that states the variance of the existing variable is accepted. Thus it can be concluded that the variance of the study subject is homogeneous. From this information, the variable data in this study can be analyzed using parametric statistics. 


\subsection{Hypothesis Test}

Based on the calculation of pretest and posttest data on the results of shooting petanque athletes, obtained a value of $p=0.000$. The result can be interpreted that $p \leq 0.05$, which means that $\mathrm{H} 0$ is not accepted and $\mathrm{H} 1$ is accepted. So the H0, which reads "no influence between the accuracy of accuracy training results on shooting results in petanque athletes aged 15-20 years", was rejected. Then H1 which reads "there is an influence between the program of accuracy training on the results of shooting in petanque athletes aged 15-20 years", is accepted. More can be found in Table 5.

Table 5. Results of Hypothesis Test Calculations

\begin{tabular}{|c|c|c|c|}
\hline Pretest-Posttest & t & df & $\begin{array}{c}\text { Sig. } \\
\text { (2-tailed) }\end{array}$ \\
\hline One Group & 14.207 & 19 & 0,000 \\
\hline
\end{tabular}

Note: $\mathrm{t}$ = $\mathrm{t}$-test; $\mathrm{df}=$ degree of freedom; sig.= signification

\section{Discussions}

Petanque is a game that uses iron balls, played by hand, the ball is thrown with the feet tightly in the circle and the goal is to bring the iron ball closer to the wooden ball (target ball). The basic techniques of petanque games consist of shooting, and pointing [35]-[37]. The shooting technique is one of the techniques that need to be mastered properly because the purpose of the petanque game is to keep the opponent's ball away from the wooden ball through shooting so that a team can win a match. Therefore, in the implementation of training, coaches must innovate so that athletes who follow training do not feel saturated with monotonous training programs that are all [35], [38], [39].

Many factors affect the ability of basic petanque techniques. The low shooting ability of athletes needs to be found the cause, whether mastery of shooting techniques is not good, or saturation of athletes during large training because of less varied training methods [7] Therefore, to improve the shooting ability of athletes, coaches are required to be able to develop a training method that can eliminate the fatigue of athletes at training.

The previous petanque athlete's conventional training program is a method of exercise that still often makes athletes bored and the allocation of time is not optimal, making athletes unable to learn petanque playing techniques well. The lack of variety of training methods in this petanque athlete training program is mainly in shooting techniques, with monotonous training athletes becoming not serious and feeling bored so they cannot maximize the abilities that exist in them. Improving the results of athlete accuracy in shooting boule to boule needs to increase the seriousness and motivation of the athletes themselves. Therefore, a more effective and efficient training method is needed so that shooting results can be better.
The research carried out is aimed at the comparison between the results of shooting pretest and the results of shooting posttest from the influence of accuracy exercises. The results of the study found a significant influence of accuracy training on the shooting results of petanque team athletes from the results of pretest shooting and posttest shooting.

Comparison of shooting results of petanque team athletes through accuracy training from pretest and posttest there is a difference from the results of the t-test with the average value. The effect of accuracy training on shooting results that were initially 10.00 increased to 15.55 , the number of increases by 05.55 showed that the effect of accuracy training on shooting results gave good results, due to a significant increase. The improved shooting ability of petanque team athletes through accuracy training can occur due to several factors including:

(1) Athletes better understand the situation of the target shooting to do shooting than do without line shooting. This is because with training the accuracy of shooting results will be better. After all, athletes are asked to be directly exposed to targets that are in the circle.

(2) Athletes who are given treatment are mostly very enthusiastic about the program given, although some are bored with the research program because in petanque sports the most influential nature is boredom. After all, athletes do something repeatedly during training.

The findings of this study explain that the accuracy of shooting results had a significant influence on improving the shooting ability of the game, but there was a difference from the average result with the calculation of t-test, pretest shooting results, and post-test with an increase of 5.55, with a pretest shooting result of 10.00 while the posttest shooting results were 15.55 . This situation shows that the influence of accuracy training on shooting results can contribute to the improvement of the game's shooting ability. Exercise will be seen after doing 16 exercises or at least 6 weeks, for example, weight training can increase muscle strength up to $50 \%$ within 6 weeks.

The influence of accuracy training on shooting results provides a kind of stability of athletes when shooting the results are perfect, but athletes who are given treatment are not used to the training model, and athletes are still accustomed to shooting exercises that return to how they were before getting treatment to perform with accuracy. Maybe they are still used to such circumstances because what athletes often do when competing they do shooting has not been maximal.

Previous research has strengthened that accuracy training can improve shooting ability [1], [25]. These accuracy exercises include eye-hand coordination, concentration, ball feeling, arm strength, arm endurance, and confidence [11], [19]. Subsequent research provided findings that precision training and training a petanque athlete's arm strength can have an impact on shooting results [13]. 
Other research results [16], With petanque sports shooting skills training models for beginners can be developed and applied in extracurricular exercises in petanque sports shooting training model schools for beginners that have been developed, evidence of this improvement is shown in the results of testing data on pretest and posttest results there is a significant difference between before and after the treatment of the model.

\section{Conclusions}

Based on the calculation of pretest and posttest data on the shooting results of petanque athletes who have obtained an accuracy training program, a value of $\mathrm{p}=0.000$ which means that $\mathrm{p}<0.05$ so that $\mathrm{H} 0$ is rejected and $\mathrm{H} 1$ is accepted. Therefore it can be concluded that there is an influence between the accuracy training program on shooting results in petanque athletes aged 15-20 years.

The implications of this research are clubs including 1) as including to include coaches for additional training programs shooting petanque team athletes; 2) Be a useful record for coaches and also petanque teams regarding the shooting ability of petanque team athletes, and; 3) For athletes, maximum programmable training will be able to contribute significantly to the improvement of the ability to be trained.

This study seeks to comply with the required provisions. But they still have limitations and weaknesses, among others, 1) Researchers cannot control other factors that affect exercise, such as psychological, rest time, and other factors; 2) The exercise model provided has not been found in previous studies, so researchers only adopt / and modify from other sports, and 3) Researchers have tried to control the seriousness of each subject in practice but the results are still some subjects who practice not seriously.

The output and analysis of this research provide the researchers giving some suggestions including 1) Coaches can choose the right training program to improve the ability to shoot games; 2) The coach also controls other factors that affect the results of the exercise, and; 3) Athletes must carry out the training program given to the coach seriously so that the results can be maximized. Finally, this study contributed to further research to involve other factors that can improve the shooting ability of petanque athletes.

\section{Acknowledgments}

The author would like to thank all those who supported this.

\section{Conflict of Interest}

All authors declare if this research doesn't have a conflict of interest.

\section{Appendix}

Table 1. The shooting Program Without Barriers in Front of Bosi

\begin{tabular}{|c|c|c|c|c|}
\hline No & Day/Time & Program Network & Duration & Information \\
\hline \multirow{5}{*}{1} & \multirow{5}{*}{$\begin{array}{l}\text { Tuesday, Thursday, } \\
\text { and Saturday }\end{array}$} & Unveiling & 2 minutes & \\
\hline & & Warming & 8 minutes & \\
\hline & & Petanque basic engineering exercises & $15-20$ minutes & \\
\hline & & $\begin{array}{c}\text { shooting exercises without using barriers } \\
\text { with a distance of } 6,7,8,9 \text { meters }\end{array}$ & $\begin{array}{c}\text { No time 30x shooting with bosi at } \\
\text { every distance }\end{array}$ & \\
\hline & & application to the games & 1 game Petanque game (13 points) & \\
\hline
\end{tabular}

Table 2. The shooting program uses barriers in front of bosi

\begin{tabular}{|c|c|c|c|c|}
\hline No & Day/Time & Program Network & Duration & Information \\
\hline \multirow{4}{*}{1} & \multirow{4}{*}{$\begin{array}{c}\text { Tuesday, Thursday, and } \\
\text { Saturday }\end{array}$} & Unveiling & 2 minutes & \\
\hline & & Warming & 8 minutes & \\
\hline & & $\begin{array}{c}\text { Basic technique petanque shooting exercises } \\
\text { using a barrier with a distance of } 6.7,8.9 \\
\text { meters } \\
\end{array}$ & $\begin{array}{c}15-20 \text { min No time } 30 \mathrm{x} \\
\text { shooting with hitting bosi At } \\
\text { each distance } \\
\end{array}$ & \\
\hline & & Application to games & $\begin{array}{c}1 \text { game/game petanque (13 } \\
\text { points) }\end{array}$ & \\
\hline
\end{tabular}




\section{REFERENCES}

[1] R. M. Rizal, M. Asmawi, and J. Lubis, "Petanque: Mental Training and Kinesthetic Perception of Shooting Accuracy,” J. Phys. Educ. Sport. Heal. Recreat., vol. 4, no. 2, pp. 102-108, 2014.

[2] E. Burhaein et al., "Instrument Physical Activity Questinnaire-Disability (IPAQ-D) Observe Test for Disability during COVID-19: Study of Validity and Reliability in 5 Countries,” Sport Sci., vol. 15, no. 1, pp. 13-20, 2021.

[3] M. Mumpuniarti, E. Burhaein, and D. T. P. Phytanza, "Phenomenology Study on The Measurement and Availability of Psychosocial Instruments Based on Video Observations in The Unified Sports Program for Children With Intellectual Disabilities in Indonesia," Sport Sci., vol. 15, no. 1, pp. 48-56, 2021.

[4] A. O. Bustomi, T. Hidayah, A. Okilanda, and D. D. Putra, "Analisis Gerak Pointing Pada Olahraga Petanque,” J. Sport Area, vol. 5, no. 1, pp. 65-75, 2020.

[5] D. T. P. Phytanza and E. Burhaein, "The Effects of Tenure, Teacher Certification, and Work Motivation on Special Needs Teacher Performance,” Univers. J. Educ. Res., vol. 8, no. 9, pp. 4348-4356, 2020.

[6] I. A. D. Pramantik, "Optimization of Gobak Sodor Based Neuroscience Learning Game as Character Education in Intellectual Disabilities,” JUMORA J. Moderasi Olahraga, vol. 1, no. 02, pp. 63-74, 2021.

[7] Yarmani and Defliyanto, "Pelatihan Dan Sosialisasi Olahraga Petanque Bagi Guru Pjok Pada Mgmp Sukaraja , Kab . Seluma Petanque Sports Training and Socialization for Pjok Teachers in Mgmp Sukaraja , Kab . Seluma,” Ilm. Pengemb. dan Penerapan IPTEKS, vol. 18, no. 1, pp. 18-20, 2020.

[8] P. Purwanto, R. Lumintuarso, and E. Burhaein, "Impact of Running Techniques through the Sprint Ability in Athletes during the COVID-19 Pandemic," Int. J. Hum. Mov. Sport. Sci., vol. 9, no. 4, pp. 717-724, 2021.

[9] N. Demirci and P. D. T. Phytanza, "Investigation of Obesity, Physical Activity and Sedentary Behaviors of Individuals with and Without Autism Spectrum Disorder during the Covid-19 Pandemic Process," JUMORA J. Moderasi Olahraga, vol. 1, no. 02, pp. 4555, 2021.

[10] Y. M. Putra, S. Purwanto, and E. Burhaein, "Effect of Limb Muscle Power Training with Leaps on Athlete's Speed during the COVID-19 Pandemic,” Int. J. Hum. Mov. Sport. Sci., vol. 9, no. 3, pp. 461-465, 2021.
[11] R. Pelana et al., "The effect of arm length, arm endurance and self-confidence on petanque shooting," $J$. Phys. Educ. Sport, vol. 21, no. 4, pp. 2381-2388, 2021.

[12] M. R. A. Prasetya, "Comparison Of Achievement Sport Systems Between Indonesia And China,” JUMORA J. Moderasi Olahraga, vol. 1, no. 2, pp. 56-62, 2021.

[13] B. Badaru, M. Rachmat Kasmad, J. Juhanis, and N. I. Anwar, "Effect of Accuracy and Muscle Strength Training on the Result of Shooting Throws in Petanque," J. Maenpo J. Pendidik. Jasm. Kesehat. dan Rekreasi, vol. 11, no. 1, p. 56, 2021.

[14] D. T. P. Phytanza, E. Burhaein, and R. Pavlovic, "Gross Motor Skills Levels in Children with Autism Spectrum Disorder during the COVID-19 Pandemic,” Int. J. Hum. Mov. Sport. Sci., vol. 9, no. 4, pp. 738-745, 2021.

[15] M. A. Sibarani and J. S. R. Manurung, "Difference in The Influence of Practice Regulating Passes and Regulating The Game Against The Accuracy of Passing in Junior Football Players,” JUMORA J. Moderasi Olahraga, vol. 1, no. 2, pp. 75-83, 2021.

[16] M. R. Rony, M. Asmawi, and J. Lubis, "Petanque: Mental Imagery and Shooting Accuracy," in Proceedings of the 4th International Conference on Sports Sciences and Health (ICSSH 2020), 2021, vol. 36, no. Icssh 2020, pp. 35-37.

[17] D. Catur and B. Mujiriah, "Survey of Physical Fitness Levels of Badminton Athletes in Binjai City , Indonesia,” JUMORA J. Moderasi Olahraga, vol. 1, no. 2, pp. 84-94, 2021.

[18] E. Burhaein, B. K. Ibrahim, and R. Pavlovic, "The Relationship of Limb Muscle Power, Balance, and Coordination with Instep Shooting Ability: A Correlation Study in Under-18 Football Athletes,” Int. J. Hum. Mov. Sport. Sci., vol. 8, no. 5, pp. 265-270, 2020.

[19] A. Purnomo and Yendrizal, "Effect of Hand-Eye Coordination, Concentration and Believe in the Accuracy of Shooting in Petanque," in 1st International Conference of Physical Education (ICPE 2019), 2020, vol. 460, no. Icpe 2019, pp. 90-96.

[20] E. Burhaein, N. Demirci, C. C. V. Lourenço, Z. Németh, and D. T. P. Phytanza, "Coping with the COVID-19 pandemic: the role of physical activity. An international position statement,” Int. Sport. Stud., vol. 43, no. 1, pp. 52-70, 2021.

[21] D. Sulistiantoro and F. B. Setyawan, "Physical Education Textbook Study: Techniques and Forms of Assessment of Knowledge and Skills of Middle School Students in Indonesia," JUMORA J. Moderasi Olahraga, vol. 1, no. 2, pp. 95-104, 2021.

E. Burhaein, B. Tarigan, and D. T. P. Phytanza, “The 
experience and understanding of the K-13 curriculum implementation of Indonesian teachers of Adapted Physical Education (APE),” Int. Sport. Stud., vol. 42, no. e, pp. 29-42, 2020.

[23] Y. F. Irawan and I. Prayoto, "Survey of Basic Technical Skill for Futsal Male Student High School,” JUMORA J. Moderasi Olahraga, vol. 1, no. 2, pp. 105-114, 2021.

[24] P. Purwanto, S. Nopembri, E. Burhaein, and D. T. P. Phytanza, "Evaluation of The Venue Management Program of The National Sports Week (PON) XVII of Riau Province, Indonesia,” Sport Sci., vol. 15, no. 1, pp. 86-96, 2021.

[25] R. M. Rizal, M. Asmawi, and J. Lubis, "Effect of self-talk on pentanque shooting accuracy,” Int. J. Hum. Mov. Sport. Sci., vol. 9, no. 4, pp. 807-813, 2021.

[26] E. Burhaein, D. T. P. Phytanza, and N. Demirci, “The development and validation of a revised Friendship Activity Scale and Adjective Checklist for use in the Indonesian Unified Sports program,” Int. Sport. Stud., vol. 42, no. e, pp. 18-28, 2020.

[27] P. Widodo and F. Zainul, "Basic Swimming Style Crawl Engineering Skills Survey in Athletes Ages 10-12,” JUMORA J. Moderasi Olahraga, vol. 1, no. 2, pp. 115124, 2021.

[28] S. Purwanto and E. Burhaein, "The Sports Development Program at the Indonesia Karate Sport Federation (FORKI) in The DIY Province of Indonesia," Sport Sci., vol. 15, no. 1, pp. 77-85, 2021.

[29] E. Burhaein, B. Tarigan, D. Budiana, Y. Hendrayana, and D. T. P. Phytanza, "Physical Activity Level of Students with Disabilities during COVID-19 Pandemic," J. Pendidik. Jasm. dan Olahraga, vol. 6, no. 2, pp. 1921, 2021.

[30] J. R. Fraenkel, N. E. Wallen, and H. H. Hyun, How to design and evaluate research in education. New York: Mc Graw Hill, 2012.

[31] R. Ardian, S. Suharjana, and E. Burhaein, "Effect of progressive and repetitive part methods against the accuracy of kicking in football extracurricular students," ScienceRise, vol. 1, no. 7, pp. 40-44, 2019.

[32] E. Burhaein, B. Tarigan, D. Budiana, Y. Hendrayana, and D. T. P. Phytanza, "Profile of changes in adaptive physical education learning during the Covid-19 pandemic," in Innovation on Education and Social Sciences, 1st ed., London: Routledge, 2022, pp. 1-10.

[33] Pengurus Besar Federasi Olahraga Petanque Indonesia, Program dan Teknik Dasar Bermain Petanque. Jakarta: PB FOPI, 2012.

[34] J. Sarwono, "PASW Statistics 18: Belajar Statistik Menjadi Mudah dan Cepat.” CV Andi Offset, Yogyakarta, 2010.

[35] B. W. Putman, Pétanque: The Greatest Game You Never Heard Of: Beyond Bocce, The Elegant \& Intelligent French Game of Boules. South Carolina, USA: CreateSpace Independent Publishing Platform, 2011.

[36] Y. F. Irawan and D. Limanto, "Pengaruh Kecerdasan Emosi dan Kesiapan Diri Terhadap Pertandingan Pada Pemain Walet Muda Futsal Academy Kebumen Tahun 2020,” JUMORA J. Moderasi Olahraga, vol. 1, no. 01, pp. 18-26, 2021.

[37] A. R. Azizah and E. P. Sudarto, "Minat Mengikuti Ekstrakurikuler Bola Voli Siswa Smp Negeri 3 Satu Atap Karangsambung Kecamatan Karangsambung Tahun Ajaran 2019/2020,” JUMORA J. Moderasi Olahraga, vol. 1, no. 01, pp. 35-44, 2021.

[38] W. G. Sutopo and Misno, “Analisis Kecepatan Tendangan Sabit Pada Pesilat Remaja Perguruan Pencak Silat Tri Guna Sakti Di Kabupaten Kebumen Tahun 2020,” JUMORA J. Moderasi Olahraga, vol. 1, no. 01, pp. 27-34, 2021.

[39] I. P. Widiyono and Mudiono, "Keterampilan Dasar Futsal Peserta Ektrakurikuler di SMK Ma’arif 1 Kebumen Tahun Ajaran 2019/2020,” JUMORA J. Moderasi Olahraga, vol. 1, no. 01, pp. 10-17, 2021. 